\title{
Antifibrotic effect of the ethyl acetate fraction of ciplukan (Physalis angulata Linn.) in rat liver fibrosis induced by $\mathrm{CCI}_{4}$
}

\author{
Enny Rohmawaty ${ }^{1 *}$ (D), Aziiz Mardanarian Rosdianto ${ }^{2}$ (D), Hermin Aminah Usman ${ }^{3}$ (D), Winda A. M. \\ Saragih $^{4}$ (D), Ade Zuhrotun 5 (D), Rini Hendriani ${ }^{6}$ (D), Yoga Windhu Wardhana ${ }^{7}$ (D), Savira Ekawardhani ${ }^{8}$ (D), \\ Hesti Lina Wiraswati ${ }^{8}$ (D), Nenny Agustanti ${ }^{9}$ (D), Muhammad Begawan Bestari ${ }^{9}$ (D), Sumartini Dewi ${ }^{10}$ \\ ${ }^{1}$ Division of Pharmacology and Therapy, Department of Biomedical Sciences, Faculty of Medicine, Universitas Padjadjaran, Bandung, Indonesia. \\ ${ }^{2}$ Veterinary Medicine Program, Department of Biomedical Sciences, Faculty of Medicine, Universitas Padjadjaran, Bandung, Indonesia. \\ ${ }^{3}$ Department of Anatomical Pathology, Faculty of Medicine, Universitas Padjadjaran, Bandung, Indonesia. \\ ${ }^{4}$ Department of Internal Medicine, Faculty of Medicine, Padjadjaran University, Bandung, Indonesia. \\ ${ }^{5}$ Department of Biological Pharmacy, Faculty of Pharmacy, Universitas Padjadjaran, Bandung, Indonesia. \\ ${ }^{6}$ Department of Pharmacology and Clinical Pharmacy, Faculty of Pharmacy, Universitas Padjadjaran, Bandung, Indonesia. \\ ${ }^{7}$ Study Center of Pharmaceutical Dosage Development, Department of Pharmaceutics and Pharmaceuticals Technology, Faculty of Pharmacy, Universitas \\ Padjadjaran, Bandung, Indonesia. \\ ${ }^{8}$ Department of Biomedical Sciences, Faculty of Medicine, Universitas Padjadjaran, Bandung, Indonesia. \\ ${ }^{9}$ Division Gastro Entero Hepatology, Department of Internal Medicine, Faculty of Medicine, Padjadjaran University, Bandung, Indonesia. \\ ${ }^{10}$ Immunology Study Center, Division Rheumatology, Department of Internal Medicine, Faculty of Medicine, Padjadjaran University, Bandung, Indonesia.
}

\section{ARTICLE INFO \\ Received on: $28 / 05 / 2021$ \\ Accepted on: 12/08/2021 \\ Available Online: 05/12/2021}

Key words:

Physalis angulata Linn., antifibrotic, carbon tetrachloride, liver fibrosis, alanine aminotransferase serum, histopathological changes.

\begin{abstract}
Ciplukan (Physalis angulata Linn.) is a Solanaceae family species and contains various active compounds with diverse therapeutic potential. The goal of this investigation was to see if the ethyl acetate fraction of ciplukan had an antifibrotic impact on liver fibrosis. The oral administration of $20 \%$ carbon tetrachloride $\left(\mathrm{CCl}_{4}\right)$ twice weekly for 8 weeks was used to cause liver fibrosis. Four weeks following fibrosis induction, ciplukan ethyl acetate fractions of 1.11 $\mathrm{mg}$ (CPL-1) and $2.22 \mathrm{mg}$ (CPL-2) were given orally. As a positive control group, vitamin E was used. When compared to the negative control, the ethyl acetate portion of $2.22 \mathrm{mg}$ (CPL-2) lowered serum alanine aminotransaminase levels $(83.95 \pm 27.675$ vs $175.23 \pm 5.641$, p-value $<0.05)$. Microscopic histopathological changes based on the better Metavir score (CPL-2 vs. negative control $=1.25 \pm 1.893 v s .3 .50 \pm 0.577 ; p$-value $<0.05)$ and Ishak score $(C P L-2 v s$. negative control $=1.50 \pm 1.000$ vs. $4.75 \pm 0.957 p$-value $<0.05)$ were demonstrated. Overall, in rat liver fibrosis induced by $\mathrm{CCl}_{4}$, these findings suggest that the ethyl acetate fraction of ciplukan has an antifibrotic effect.
\end{abstract}

\section{INTRODUCTION}

Liver fibrosis is the leading cause of mortality worldwide. In 2016, the Centers for Disease Control and Prevention stated that there were 4.9 million persons in the United States who had liver disease. Liver diseases are the sixth leading cause of death at 2564 years of age (Shipley et al., 2019). Many etiologies cause liver

\footnotetext{
${ }^{*}$ Corresponding Author

Enny Rohmawaty, Division of Pharmacology and Therapy, Department of Biomedical Sciences, Faculty of Medicine, Universitas Padjadjaran, Bandung, Indonesia.E-mail: e.rohmawaty@unpad.ac.id
}

fibrosis, including genetics, chronic viral hepatitis, alcohol abuse, exposure to drugs and toxic substances, autoimmune illnesses, metabolic diseases, cholestatic disorders, prolonged venous stasis in the liver, and parasite infections (Ahmad and Ahmad, 2012; Weiskirchen et al., 2018).

Liver fibrosis is a pathological condition that develops when the liver's stiff fibrotic connective tissue proliferates and accumulates abnormally. The fibrotic connective tissue that creates scar tissue is a typical response to injury, but chronic stimulation of inflammatory cells promotes abnormal tissue repair in the fibrosis formation process. Hepatic stellate cells (HSCs) are activated and produce collagen, glycoproteins 
(like fibronectin), and proteoglycans as a result of this process, which produces cytokines, growth factors, and other activation molecules. Hepatic stellate cell abnormal deposition products are followed by poor collagenolysis, resulting in the formation of fibrosis tissue (Ahmad and Ahmad, 2012).

Transforming growth factor-beta (TGF- $\beta$ ) is a cytokine and growth factor involved in the progression of liver disease (Ahmad and Ahmad, 2012; Fabregat et al., 2016). Chronic inflammation results in a high level of TGF- $\beta$, which causes the activation of HSC, myofibroblast, and enormous hepatocytes apoptosis, all of which contribute to liver fibrosis (Fabregat et al., 2016). The activated HSCs trigger TGF- $\beta$ production, one of the most potent stellate cell mitogens. The activated HSCs are also upregulated and enhance the autocrine effect of TGF- $\beta 1$ (Ahmad and Ahmad, 2012; Biernacka et al., 2011). TGF- $\beta$ is also synthesized by liver endothelial cells and Kupffer cells (Ahmad and Ahmad, 2012).

Fibrosis causes upregulation and activation of TGF- $\beta$ and thus modulates fibroblast function. TGF- $\beta$ also induces transdifferentiation of myofibroblast, while matrix preservation is promoted. Some pathways, such as classical ALK5/Smad3, are implicated in the fibrosis process and have been demonstrated in some experimental settings. The effect of TGF- $\beta$ as a profibrotic agent is mediated through an effector like connective tissue growth factor. Hence, TGF- $\beta$ may be an attractive target of fibrosis therapy (Biernacka et al., 2011).

Recent molecular biology studies have identified elements involved in the fibrosis process in the liver. The discovery of new complementary therapeutic approaches to liver fibrosis has been aided by improved comprehension of the pathogenesis at the molecular level. Several studies have shown the amazing effects of natural ingredients such as silymarin and curcumin in treating liver fibrosis (Ahmad and Ahmad, 2012).

Various studies also revealed that some ingredients have antifibrosis activity based on their mechanism of action which include antioxidant effects that contribute to preventing inflammation, stimulating the breakdown of extracellular matrix (ECM), impairing HSC activation and multiplication, decreasing ECM formation by HSC, impeding HSC contractile response, and activation of HSC apoptotic process (Ahmad and Ahmad, 2012).

The existing antifibrotic strategies and their chemical compounds are TGF- $\beta$ inhibition [chemical compounds like N-acetyl-L-cysteine, prostacyclin, IL-10, IFN- $\gamma$, and prostaglandin E2 (PGE2) inhibits], PPAR- $\gamma$ stimulation [curcumin, thiazolidinediones, and 15-deoxy-delta12,14prostaglandin $\mathrm{J}(2)$ ], apoptosis stimulation (adiponectin, IGF1, gliotoxin, and sulfasalazine), and suppression/inhibition of HSCs proliferation and activation (brain natriuretic peptide, retinoic acid, L-cysteine, serine protease inhibitor camostat mesylate, dilinoleoyl phosphatidyl colchicines, and PPAR- $\gamma$ antagonist rosiglitazone) (Ahmad and Ahmad, 2012).

An approved standard therapy for liver fibrosis has not been established. The available treatments are varied, from lifestyle modification to liver transplant. Many factors influence the choice of liver fibrosis therapy, including patient adherence, access to health services, and the severity of the disease.
Research conducted to find the safe, effective, cheap, and affordable antifibrosis drug would improve the quality of life for fibrosis patients. Ciplukan (Physalis angulata Linn.), an alternative medicine of antifibrosis, grows easily in several tropical and subtropical countries and has some exciting information due to some systematic review and experimental studies (RengifoSalgado and Vargas-Arana, 2013).

The herb ciplukan is a species of the Solanaceae family with various therapeutic potentials, including hypoglycemic agent, microbicidal, antiviral, immune system modulation, antiinflammatory, antioxidant, and antineoplastic. Saponins, flavonoids, polyphenols, alkaloids, physalin B, physalin $\mathrm{D}$, physalin $\mathrm{F}$, protein, chlorogenic citric withangulatin A (WA), palmitic acid, acetate acid, protein, vitamin $\mathrm{C}$, tannins, and malic acid are among the active components found in ciplukan. Antioxidant compounds are substances that include these components (Dewi et al., 2019; Luthfiyanti et al., 2021; Rengifo-Salgado and Vargas-Arana, 2013). Saponins, physalins, and WA provide anti-inflammatory, antiproliferative, antiangiogenesis, and anticancer activities (Dewi et al., 2019). As an immunomodulator, ciplukan has three major antifibrotic pathways. The first pathway is based on phenol components (flavonoid, tannin, and phenylpropane), while the second and third pathways are based on secosteroid and saponin compounds (Dewi et al., 2019).

In a recently published double-blind, randomized clinical trial, ethanol extract of the herb ciplukan in patients with systemic sclerosis (scleroderma) who received standard therapy, by monitoring the parameters of skin fibrosis repair and serum fibrosis biomarkers, showed that ciplukan herb has an antifibrosis effect on the skin. It is thought that this herb has anti-inflammatory, antioxidant, and antiproliferative properties (Dewi et al., 2019). The study also demonstrated that fibrosis is a treatable and reversible illness. We hypothesized that the ciplukan herb could have an antifibrotic effect on liver fibrosis based on these findings. The goal of this investigation was to see if the ethyl acetate fraction of ciplukan had an antifibrotic impact on liver fibrosis.

\section{MATERIALS AND METHODS}

\section{Reagents}

CC14, PBS (phosphate-buffered saline), xylol, hematoxylin-eosin (HE), Masson's trichrome (MT), and ethanol were purchased from Sigma-Aldrich (Merck KGaA, Darmstadt, Germany), and liquid nitrogen, corn oil (Mazola), neutral buffer formalin (Bio-Optica, Milano, Italy), alanine aminotransferase (ALT) kit (Randox, Cat. No. AL1205, United States) were used. All additional compounds were purchased from local commercial vendors.

\section{Plant material}

All parts of $P$. angulata Linn., except the roots, were gathered from December 2019 to February 2020 from several areas in West Java, Indonesia. The harvested specimens were identified at the Biology Department, Faculty of Mathematics and Natural Sciences, Universitas Padjadjaran.

\section{Ethyl acetate fraction of P. angulata Linn. preparation}

The extraction method was the cold maceration process using a solvent that was stirred several times, carried out at room 
temperature. All parts of ciplukan herbs (except roots) were soaked with $50 \%$ ethanol for $3 \times 24$ hours. A rotary vacuum evaporator was used to thicken the filtrate. Next, thick freeze-dried ciplukan was extracted into a dry extract. A portion of the thick ethanol extract was diluted in hot water and fractionated using the liquid-liquid extraction method with ethyl acetate as the solvent. Each extractant was then evaporated using a rotary vacuum vaporizer, while the raffinate was evaporated using a freeze dryer. From the fractionation process, ethyl acetate fraction and water fraction were obtained. According to a prior study conducted by Dewi et al. (2019), the dose of the ethyl acetate fraction of ciplukan was $375 \mathrm{mg} /$ day/subject. After multiplying the dose with 0.018 [Laurence-Bacharach's coefficient and the yield of the fraction (16.5\%)], the dose of the ethyl acetate fraction of ciplukan in rats was $1.11 \mathrm{mg}$ (CPL-1) and $2.22 \mathrm{mg}$ (CPL-2).

\section{Animals}

Male adult Wistar rats, 12 weeks old and 200-230 g body weights, were purchased from Animal Laboratories Divisions of PT, Biofarma, Parongpong, West Java, Indonesia (https://goo.gl/maps/ Sf6MciabGJYWSjbb7). Rats were caged at $24^{\circ} \mathrm{C}$ with a 12 -hour light/12-hour dark cycle (light was switched on from 6 am until $6 \mathrm{pm}$ ), $55 \%$ relative humidity and regular diet used Prospets (water $10.98 \%$, protein $24.59 \%, 9.70 \%, 48.30 \%$, calcium $0.8 \%, \mathrm{NaCl} 0.1 \%$ ) were purchased from Surya Sains Indonesia and water as much as desired for 7 days in the Animal Laboratory, Physiology Division, Faculty of Medicine, Universitas Padjadjaran. The rats were sacrificed using ketamine xylazine $(100+5 \mathrm{mg} / \mathrm{kg} \mathrm{BW})$ anesthesia (Albrecht et al., 2014), and then liver was removed, cleaned in PBS solution, weighed, and quickly freeze in liquid nitrogen before being kept at $-80^{\circ} \mathrm{C}$ until use. The blood samples were centrifuged for 3 minutes at $15,000 \mathrm{rpm}$ and then kept at $-20^{\circ} \mathrm{C}$ until needed.

\section{Fibrosis model}

$\mathrm{CCl}_{4}$ was used to create liver fibrosis in rats by administering orally $1 \mathrm{~mL} / \mathrm{kg}$ body weight of $20 \% \mathrm{CCl}_{4} /$ corn oil twice weekly for 8 weeks (Lin et al., 2006).

\section{Treatments}

The dose of ethyl acetate fraction of $P$. angulate Linn. (CPL, ciplukan locally named on West Java, Indonesia) was adjusted based on the findings of a prior study (Dewi et al., 2019). The rats were divided into seven groups at random ( $n$ $=5)$ : negative control group $\left(\mathrm{CCl}_{4}\right.$-induced), positive control group $\left(\mathrm{CCl}_{4}\right.$-induced + Vitamin E $10 \mathrm{IU} / \mathrm{kg} /$ day) (Zamin et al., $2010)$, standard treatment group one $\left(\mathrm{CCl}_{4}\right.$-induced + Vit. $\mathrm{E}+$ CPL-1) (1.11 mg), standard treatment group two $\left(\mathrm{CCl}_{4}\right.$-induced + Vit. E + CPL-2) (2.22 mg), a single dose of CPL group $\left(\mathrm{CCl}_{4}{ }_{-}\right.$ induced + CPL-1), a double dose of CPL group ( $\mathrm{CCl}_{4}$-induced + CPL-2), and control group (unstimulated, no treatment). The $\mathrm{CCl}_{4}$-induced was given orally every day for 8 weeks. The treatment of Vit. E and CPL was given orally for 4 weeks after liver fibrosis was induced in rats.

\section{Sample preparation}

The serum followed centrifugation for 3 minutes at $15,000 \mathrm{rpm}$ at $4{ }^{\circ} \mathrm{C}$. The liver of BNF $10 \%$ was sliced into $5 \mu \mathrm{m}$ by microtome. The liver tissues were fixed in
4\% paraformaldehyde phosphate buffer solution, paraffinembedded before being stained with HE and MT, and then examined under a light microscope.

\section{Biochemical assays}

ALT activities on serum samples were measured using an ALT kit (Randox, Cat. No. AL1205, United States). The steps for the analysis were carried out using the kit protocol.

\section{Histopathological examination}

Histopathological changes of liver fibrosis were evaluated by Metavir score (F0-F4) with F0 being no fibrosis, F1 existing fibrosis with portal zones expansion, F2 existing fibrosis with mostly portal zones expansion and infrequent bridging, F3 existing fibrosis with mostly portal zones expansion, significant bridging, and infrequent nodules, and F4 presence of cirrhosis. Metavir's transition from F2 to F3 begins when the biopsy reveals more fibrous septa than portal tracts without septa. Cirrhosis is characterized by nodular fibrosis, which represents hepatocyte nodules and mutilates liver tissue (Sebastiani, 2009).

In addition to the Metavir score, we assess histopathological changes using Ishak stage (0-6) with 0 being no fibrosis, 1 being fibrosis in certain portal areas, either with short fibrous septa), 2 being fibrosis in most portal areas, either with or without short fibrous septa, 3 being fibrosis in most portal areas with an infrequent portal to portal bridging, 4 being fibrosis of portal areas with significant bridging (portal to portal as well as a portal to central), 5 being significant bridging (portal-portal and/ or portal-central) with infrequent nodules (incomplete cirrhosis)), and 6 being cirrhosis, probable or definite (Goodman, 2007).

\section{Statistical analysis}

The acquired data were subjected to a one-way analysis of variance (ANOVA) using the SPSS (version 20) statistical tool (IBM SPSS Statistics for Windows, version XX, IBM Corp., Armonk, N.Y). When ANOVA revealed significant differences, the LSD (Least Significant Difference) test was used to examine the differences between the means of the treatment and control groups. In a nonparametric study, the Kruskal-Wallis H-test was used to assess differences between groups, and the Mann-Whitney U-test was used to determine the significance of those differences.

\section{RESULTS AND DISCUSSION}

\section{Serum marker (ALT)}

Table 1 presents the administration of the ethyl acetate fraction of ciplukan in both dose one (CPL-1) and dose two (CPL$2)$. When compared to the $\mathrm{CCl}_{4}$-treated group, its demonstrated a significant decrease in serum ALT $(p<0.05)$. The histogram shows serum ALT concentration in each group (Fig. 1). Apart from CPL-1 and CPL-2, there was no statistically significant reduction in serum ALT levels in the other groups $(p>0.05)$.

\section{Histopathological changes}

$H \& E$ and MT staining were utilized to examine the histopathological changes of a liver specimen. As measured by the Metavir score, the $\mathrm{CCl}_{4}$-treated group had portal fibrosis and cirrhosis (F3 and F4) in comparison with the control group, where typical lobular architecture was found (Fig. 2). The histological 
Table 1. The effect of the ethyl acetate fraction of ciplukan (CPL-1 and CPL-2), vitamin E, and the combination of ciplukan fraction-vitamin $\mathrm{E}$ on $\mathrm{CCl}_{4}$-treatexd rats.

\begin{tabular}{ccccc}
\hline & \multicolumn{3}{c}{ ALT } \\
\cline { 2 - 4 } Variables & Mean \pm SD & Median & Range (min-max) & $p$-value \\
\hline Normal & $86.63 \pm 25.569$ & 73.50 & $70.30-116.10$ & 0.057 \\
$\mathrm{CCl}_{4}$ (negative control) & $175.23 \pm 5.641$ & 175.05 & $168.50-182.30$ & \\
$\mathrm{CCl}_{4}$ (negative control) & $175.23 \pm 5.641$ & 175.05 & $168.50-182.30$ & $0.029^{*}$ \\
$\mathrm{CCl}+\mathrm{CPL}-1$ & $77.28 \pm 12.857$ & 71.50 & $69.60-96.50$ & \\
$\mathrm{CCl}_{4}$ (negative control) & $175.23 \pm 5.641$ & 175.05 & $168.50-182.30$ & $0.029^{*}$ \\
$\mathrm{CCl}_{4}+\mathrm{CPL}-2$ & $83.95 \pm 27.675$ & 75.20 & $61.80-123.60$ & \\
$\mathrm{CCl}_{4}$ (negative control) & $175.23 \pm 5.641$ & 175.05 & $168.50-182.30$ & 0.343 \\
CCl + Vit E & $145.20 \pm 89.589$ & 115.70 & $78.10-271.30$ & \\
$\mathrm{CCl}_{4}$ (negative control) & $175.23 \pm 5.641$ & 175.05 & $168.50-182.30$ & 0.190 \\
$\mathrm{CCl}_{4}+$ Vit E + CPL-1 & $134.84 \pm 85.882$ & 106.10 & $282.90-208.00$ & \\
$\mathrm{CCl}_{4}$ (negative control) & $175.23 \pm 5.641$ & 175.05 & $168.50-182.30$ & 0.629 \\
$\mathrm{CCl}_{4}+$ Vit E + CPL-2 & $136.60 \pm 66.952$ & 131.40 & $72.40-206.00$ & \\
\hline
\end{tabular}

Each group's values are provided as mean \pm SD for five animals. ALT is measured in IU/l units

If the data is normally distributed and has homogenous variants, the $p$-value was calculated using the LSD test; if the data is not normally distributed and the variance is not homogeneous, the Mann-Whitney test was used.

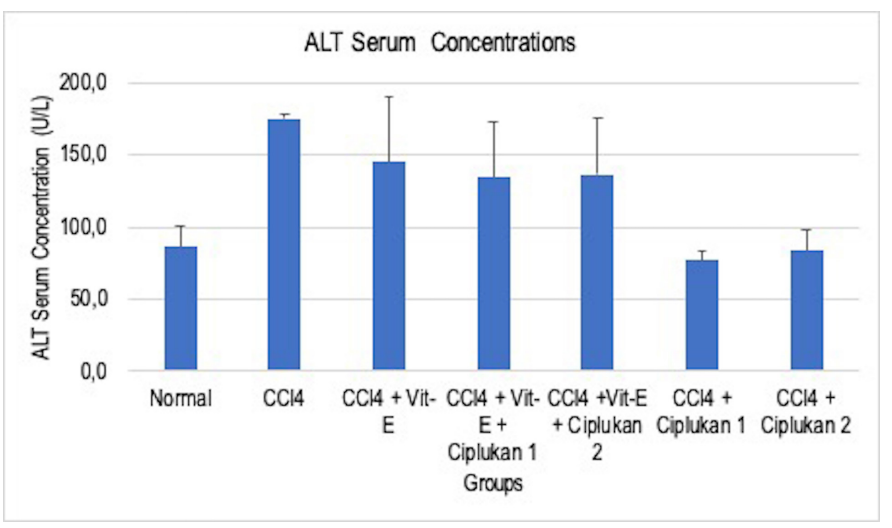

Figure 1. Effect of ciplukan fraction (CPL-1 and CPL-2), vitamin E, and the combination of ciplukan fraction-vitamin $\mathrm{E}$ on $\mathrm{CCl}_{4}$-treated rats. The histogram shows serum ALT concentration in each group: the negative control, $\mathrm{CCl}_{4}$ only, $\mathrm{CCl}_{4}+$ Vit. E, $\mathrm{CCl}_{4}+$ Vit. E + ciplukan $1, \mathrm{CCl}_{4}+$ Vit. E + ciplukan 2, $\mathrm{CCl}_{4}+$ ciplukan 1 , and $\mathrm{CCl}_{4}+$ ciplukan 2 . The difference was measured between each group. Significance was defined at $p$-value $<0.05$.

score improved after treatment with the ethyl acetate fraction of CPL-2, while the degree of liver fibrosis and fibrous septa decreased.

TheevaluationofhistopathologicalchangesusingMetavir score and Ishak score was analyzed statistically. Using ANOVA, the mean value of both scoring systems was significantly different $(p<0.0001)$ (Tables 2 and 3).

The treatment of the ethyl acetate fraction of CPL-2 significantly lowered both histological fibrosis scores (Metavir and Ishak scores) compared to the negative control group $\left(\mathrm{CCl}_{4}\right.$-treated group) $(p<0.05)$ (Tables 4 and 5).

Figure 3 shows the mean value of both Metavir and Ishak scoring for liver fibrosis from each group.

\section{Discussion}

This study revealed that $\mathrm{CCl}_{4}$ was a hazardous material that produced free radicals known as reactive oxygen and nitrogen species (ROS and RNS). Inside the cell membrane, these oxidative stress components would directly induce crucial molecule breakdowns, like DNA or polyunsaturated fatty acids. This process induces lipid peroxidation and enzyme inactivation, resulting in liver cell necrosis (Ebeid et al., 2015). Due to $\mathrm{CCl}_{4}$ exposure, the mechanism of fibrosis could lead to the PPAR pathway stimulation process, arachidonic acid metabolism, retinol metabolism, glycolysis/gluconeogenesis, and glycerolipid metabolism (Dong et al., 2016). Several cytokines and growth factors, such as NF-kB (Nuclear Factor Kappa B), TNF (Tumour Necrosis Factor), and TGF- $\beta$ (Transforming Growth Factor- $\beta$ ) play critical roles in hepatic fibrosis, like activating the hepatic inflammatory pathway and stimulating Kupffer cells and hepatic stellate (Luedde and Schwabe, 2011).

The results revealed that serum ALT concentrations were higher in the $\mathrm{CCl}_{4}$-treated group (Table 1) and microscopically showed loss of normal morphology of hepatocytes architecture, clear collagen deposition, and formation of fiber segmentation formation (Fig. 2 b and 2c). Hepatic mitochondrial enzymes, which are related to an increase in hepatic lipid peroxidation, are secreted by necrotic hepatocytes cells. Kupffer cells will become activated by lipotoxic mediators and intracellular signals (ContrerasZentella and Hernández-Muñoz, 2016).

Significant alterations in serum ALT concentration were found in the CPL-2 group, along with microscopic histological changes that indicated a healing process on hepatocytes, such as a reduction in fibrosis. This conclusion was based on the gradual decrease of Ishak score and Metavir score criteria.

The most striking findings of this pathological investigation were hepatocyte destruction, inflammation, and 

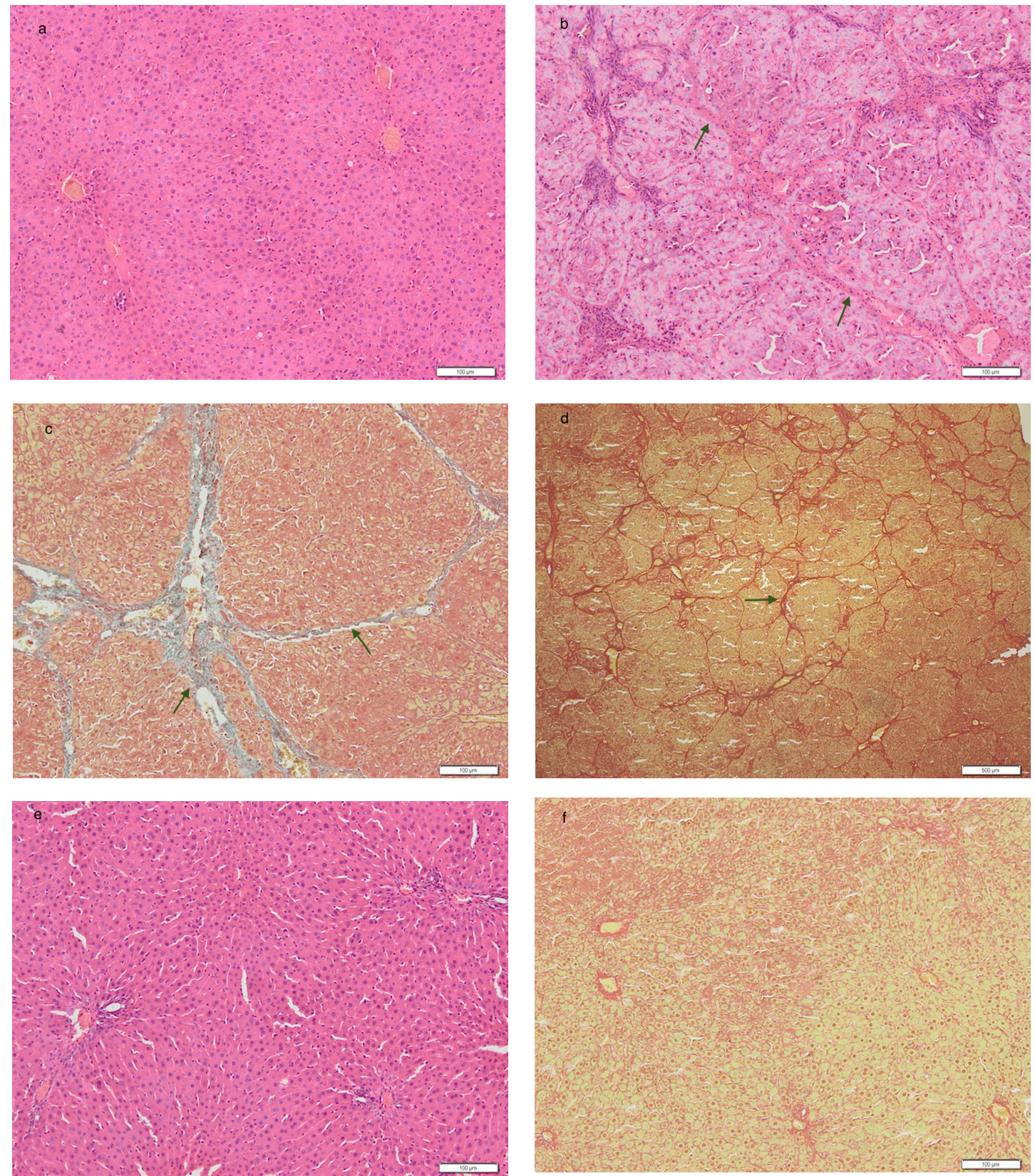

Figure 2. Histopathological changes in the normal group [a], $\mathrm{CCl}_{4}$-treated group / negative control $[\mathrm{b}=\mathrm{HE}$ stain, $100 \times ; \mathrm{c}=\mathrm{TM}$ stain 100×; and $\mathrm{d}=\mathrm{TM}$ stain $20 \times]$ and treatment group with ethyl acetate fraction of ciplukan $2.22 \mathrm{mg}(\mathrm{CPL}-2)(\mathrm{e}=\mathrm{CPL}-2 \mathrm{HE}$ stain, 100×; $\mathrm{f}=\mathrm{CPL}-2 \mathrm{TM}$ stain, 20×). Histological evaluation of ciplukan fraction on CCl4-induced liver damage was performed using HE staining and Trichome Masson staining on liver tissue under a light microscope (original magnification; $\times 100$ ). $\mathrm{On} \mathrm{CCl}_{4}{ }^{-}$ induced liver damage, there was pseudolobular formation (cirrhosis) (signing by $\rightarrow$ ), which in the treatment group with $2.22 \mathrm{mg}$ ciplukan fraction (CPL-2), the pseudolobular formation disappeared and returned to normal conditions.

fibrosis. Contreras-Zentella and Hernández-Muñoz (2016) identified that inflammation was an element of the tissue repairing process which contributes to the deposition of ECM and fibrosis in the liver (Contreras-Zentella and Hernández-Muñoz, 2016). The significant differences in ALT serum level on the CPL-2 group showed the possibility for the inhibition of inflammatory activity and hepatocyte damage.

Phytochemical studies of ciplukan revealed that this herb contained phenol (flavonoids, tannin, and phenylpropane), secosteroid (physalin, withangulin, and others), and saponin
(Dewi et al., 2019; Rengifo-Salgado and Vargas-Arana, 2013). Phenol components act as antioxidants and immunomodulators. Antioxidative defenses have several primary roles, including suppressing and scavenging ROS production, repairing and boosting the damage, and activating antioxidant protein and enzyme expression (Contreras-Zentella and Hernández-Muñoz, 2016). Secosteroids and saponin exert anti-inflammatory and antiproliferative effects that inhibit the fibrosis process (Dewi et al., 2019). Another study stated that saponin had been proven to inhibit $\mathrm{NF}-\mathrm{kB}$ expression in hepatic cell carcinoma and activate the PPAR 
Table 2. Comparison of Metavir scores among groups.

\begin{tabular}{ccccc}
\hline & \multicolumn{3}{c}{ Metavir scores } \\
\cline { 2 - 5 } Variables & Mean \pm SD & Median & $\begin{array}{c}\text { Range } \\
\text { (min-max) }\end{array}$ & $\boldsymbol{p}$-value \\
\hline Normal & $0.00 \pm 0.00$ & 0.00 & $0.00-0.00$ & $0.0001^{* *}$ \\
$\mathrm{CCl}_{4}$ (negative control) & $3.50 \pm 0.577$ & 3.50 & $3.00-4.00$ & \\
$\mathrm{CCl}_{4}+\mathrm{CPL}-1$ & $3.75 \pm 0.500$ & 4.00 & $3.00-4.00$ & \\
$\mathrm{CCl}_{4}+\mathrm{CPL}-2$ & $1.25 \pm 1.893$ & 0.50 & $0.00-4.00$ & \\
$\mathrm{CCl}_{4}+$ Vit E & $3.75 \pm 0.500$ & 4.00 & $3.00-4.00$ & \\
$\mathrm{CCl}_{4}+$ VitE + CPL-1 & $2.20 \pm 1.095$ & 2.00 & $1.00-4.00$ & \\
$\mathrm{CCl}_{4}+$ Vit E + CPL-2 & $3.33 \pm 0.577$ & 3.00 & $3.00-4.00$ & \\
\hline
\end{tabular}

The one-way ANOVA test was used to determine the p-value (if the data is normally distributed and has a homogeneous variance).

The Kruskal-Wallis test is a different option (if the variance is not homogeneous and the data is not distributed normally).

*Statistically significant $(p<0.05)$.

Table 3. Comparison of Ishak scores among groups.

\begin{tabular}{ccccc}
\hline & \multicolumn{3}{c}{ Ishak scores } \\
\cline { 2 - 5 } Variables & Mean \pm SD & Median & $\begin{array}{c}\text { Range } \\
(\text { min-max })\end{array}$ & $p$-value \\
\hline Normal & $0.00 \pm 0.00$ & 0.00 & $0.00-0.00$ & \\
$\mathrm{CCl}_{4}$ (negative control) & $4.75 \pm 0.957$ & 4.50 & $4.00-6.00$ & \\
$\mathrm{CCl}_{4}+\mathrm{CPL}-1$ & $5.50 \pm 1.000$ & 6.00 & $4.00-6.00$ & $0.0001^{* *}$ \\
$\mathrm{CCl}_{4}+\mathrm{CPL}-2$ & $1.50 \pm 2.380$ & 0.50 & $0.00-5.00$ & \\
$\mathrm{CCl}_{4}+$ Vit E & $5.00 \pm 0.817$ & 5.00 & $4.00-6.00$ & \\
$\mathrm{CCl}_{4}+$ Vit E+CPL-1 & $3.00 \pm 1.414$ & 3.00 & $1.00-5.00$ & \\
$\mathrm{CCl}_{4}+$ Vit E+CPL-2 & $4.33 \pm 0.577$ & 4.00 & $4.00-5.00$ & \\
\hline
\end{tabular}

The one-way ANOVA test was used to determine the p-value (if the data is normally distributed and has a homogeneous variance).

An alternative is the Kruskal-Wallis test (if the variance is not homogeneous and the data is not distributed normally).

*Statistically significant $(p<0.05)$.

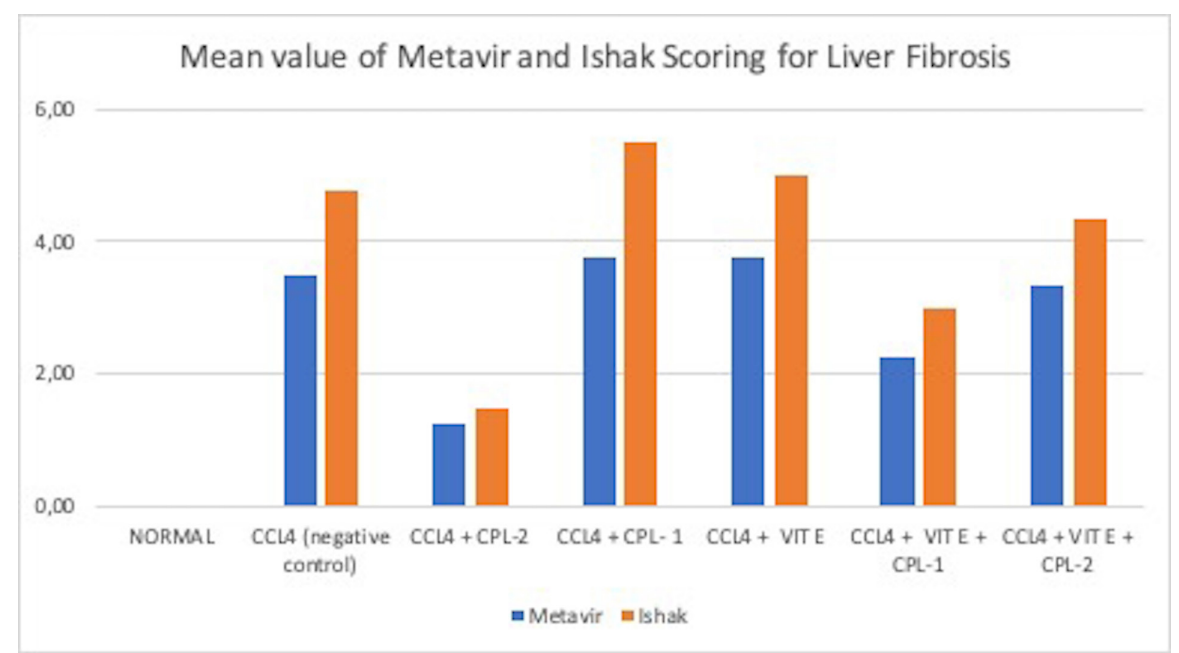

Figure 3. Comparison of the mean value for Metavir and Ishak Scores from each group. The histogram demonstrates liver fibrosis scoring using both Metavir and Ishak scoring in each group: the negative control, $\mathrm{CCl}_{4}$ only, $\mathrm{CCl}_{4}+$ Vit. $\mathrm{E}, \mathrm{CCl}_{4}+$ Vit. $\mathrm{E}+$ ciplukan $1, \mathrm{CCl}_{4}+\mathrm{Vit}$. $\mathrm{E}+$ ciplukan $2, \mathrm{CCl}_{4}+$ ciplukan 1, and $\mathrm{CCl}+$ ciplukan 2 . The difference was measured between each group. Significance was defined at $p$-value $<0.05$. 
Table 4. Comparison of Metavir scores between the negative control ( $\mathrm{CCl}_{4}$-treated group) and other groups.

\begin{tabular}{ccccc}
\hline & \multicolumn{3}{c}{ Metavir scores } \\
\cline { 2 - 5 } Variables & Mean \pm SD & Median & $\begin{array}{c}\text { Range } \\
\text { (min-max) }\end{array}$ & $\boldsymbol{p}$-value \\
\hline Normal & $0.00 \pm 0.00$ & 0.00 & $0.00-0.00$ & $0.0001^{* *}$ \\
$\mathrm{CCl}_{4}$ (negative control) & $3.50 \pm 0.577$ & 3.50 & $3.00-4.00$ & \\
$\mathrm{CCl}_{4}$ (negative control) & $3.50 \pm 0.577$ & 3.50 & $3.00-4.00$ & 0.715 \\
$\mathrm{CCl}_{4}+\mathrm{CPL}-1$ & $3.75 \pm 0.500$ & 4.00 & $3.00-4.00$ & \\
$\mathrm{CCl}_{4}$ (negative control) & $3.50 \pm 0.577$ & 3.50 & $3.00-4.00$ & $0.003^{*}$ \\
$\mathrm{CCl}+\mathrm{CPL}-2$ & $1.25 \pm 1.893$ & 0.50 & $0.00-4.00$ & \\
$\mathrm{CCl}_{4}$ (negative control) & $3.50 \pm 0.577$ & 3.50 & $3.00-4.00$ & 0.715 \\
CCl + Vit E & $3.75 \pm 0.500$ & 4.00 & $3.00-4.00$ & \\
$\mathrm{CCl}_{4}$ (negative control) & $3.50 \pm 0.577$ & 3.50 & $3.00-4.00$ & 0.054 \\
$\mathrm{CCl}_{4}+$ Vit E + CPL-1 & $2.20 \pm 1.095$ & 2.00 & $1.00-4.00$ & \\
$\mathrm{CCl}_{4}$ (negative control) & $3.50 \pm 0.577$ & 3.50 & $3.00-4.00$ & 0.822 \\
$\mathrm{CCl}_{4}+$ Vit E + CPL-2 & $3.33 \pm 0.577$ & 3.00 & $3.00-4.00$ & \\
\hline
\end{tabular}

$p$-value was tested using the LSD test (if the data is normally distributed and has homogeneous variants) and the alternative Mann-Whitney test (if the variance is not homogeneous and the data is not distributed normally).

*Statistically significant $(p<0.05)$.

Table 5. Comparison of Ishak scores between the negative control $\left(\mathrm{CCl}_{4}\right.$-treated group) and the other groups.

\begin{tabular}{ccccc}
\hline & \multicolumn{3}{c}{ Ishak Scores } \\
\cline { 2 - 5 } Variables & Mean $\pm \mathbf{S D}$ & Median & $\begin{array}{c}\text { Range } \\
\text { (min-max) }\end{array}$ & $\boldsymbol{p}$-value \\
\hline Normal & $0.00 \pm 0.00$ & 0.00 & $0.00-0.00$ & $0.0001^{* *}$ \\
$\mathrm{CCl}_{4}$ (negative control) & $4.75 \pm 0.957$ & 4.50 & $4.00-6.00$ & \\
$\mathrm{CCl}_{4}$ (negative control) & $4.75 \pm 0.957$ & 4.50 & $4.00-6.00$ & 0.431 \\
$\mathrm{CCl}_{4}+\mathrm{CPL}-1$ & $5.50 \pm 2.380$ & 6.00 & $4.00-6.00$ & \\
$\mathrm{CCl}_{4}$ (negative control) & $4.75 \pm 0.957$ & 4.50 & $4.00-6.00$ & $0.002 *$ \\
$\mathrm{CCl}_{4}+\mathrm{CPL}-2$ & $1.50 \pm 1.000$ & 0.50 & $0.00-5.00$ & \\
$\mathrm{CCl}_{4}$ (negative control) & $4.75 \pm 0.957$ & 4.50 & $4.00-6.00$ & 0.792 \\
$\mathrm{CCl}_{4}+$ Vit E & $5.00 \pm 0.817$ & 5.00 & $4.00-6.00$ & \\
$\mathrm{CCl}_{4}$ (negative control) & $4.75 \pm 0.957$ & 4.50 & $4.00-6.00$ & 0.060 \\
$\mathrm{CCl}_{4}+$ Vit E + CPL-1 & $3.00 \pm 1.414$ & 3.00 & $1.00-5.00$ & \\
$\mathrm{CCl}_{4}$ (negative control) & $4.75 \pm 0.957$ & 4.50 & $4.00-6.00$ & 0.684 \\
$\mathrm{CCl}_{4}+$ Vit E + CPL-2 & $4.33 \pm 0.577$ & 4.00 & $4.00-5.00$ & \\
\hline
\end{tabular}

The LSD test (if the data is normally distributed and has homogeneous variants) and the alternative MannWhitney test were used to get the p-value (if the variance is not homogeneous and the data is not distributed normally).

*Statistically significant $(p<0.05)$.

pathway (Li et al., 2014). The immunosuppressive action of WA, which is contained in "ciplukan," has been demonstrated through direct activation of HO-1 expression to limit the T lymphocyte overexpression and modifies Th1/Th2-type balance (Sun et al., 2011). Upregulation of endogenous HO-1 expression may modify immunity and protect cells from harm, according to a prior study (Sun et al., 2011). Another study stated that ciplukan's active ingredient physalin D reduced liver fibrosis by blocking the TGF- $\beta$ /
SMAD and YAP (Yes-associated Protein) signaling pathway (Xiang et al., 2020).

\section{CONCLUSION}

This study revealed that the ethyl acetate fraction of ciplukan ( $P$. angulata Linn.) $2.22 \mathrm{mg}$ significantly reduced the ALT serum level and markedly ameliorated hepatic fibrosis in rat liver fibrosis induced by $\mathrm{CCl} 4$. These findings suggested that ciplukan has 
an antifibrotic effect. As a promising therapeutic drug candidate for treating liver fibrosis, an in-depth understanding of the antifibrotic mechanism of ciplukan needs to be investigated further.

\section{ACKNOWLEDGMENT}

The Indonesian Endowment Fund for Education/ Lembaga Pengelola Dana Pendidikan (LPDP) provided financial support to this project.

\section{CONFLICT OF INTERESTS}

In this study, the authors declare that they have no financial or other conflicts of interest.

\section{FUNDING}

The Indonesian Ministry of Finance provided financing for this study through the Indonesia Endowment Fund for Education (LPDP, Lembaga Pengelola Dana Pendidikan).

\section{AUTHORS' CONTRIBUTIONS}

All authors had significant contributions to the study design and consented to be responsible for all parts of the process. All authors committed to the article preparation and critically redrafted it for essential intellectual value. The authors also agreed to submit the article to the present journal and gave ultimate approval of the final draft. Based on the requirements/guidelines of the International Committee of Medical Journal Editors (ICMJE), all authors are qualified to be authors.

\section{ETHICAL APPROVAL}

The Ethics Committee of the Faculty of Medicine, Universitas Padjadjaran, Indonesia (document number 1009/UN6. $\mathrm{KEP} / \mathrm{EC} / 2020$ ), approved the animal handling, maintenance, and euthanasia protocols.

\section{PUBLISHER'S NOTE}

Regarding jurisdictional claims in published institutional affiliation, this publication maintains a neutral stance.

\section{REFERENCES}

Ahmad A, Ahmad R. Understanding the mechanism of hepatic fibrosis and potential therapeutic approaches. Saudi J Gastroenterol, 2012; 18(3):155-67. doi:10.4103/1319-3767.96445

Albrecht M, Henke J, Tacke S, Markert M, Guth B. Effects of isoflurane, ketamine-xylazine and a combination of medetomidine, midazolam and fentanyl on physiological variables continuously measured by telemetry in Wistar rats. BMC Vet Res, 2014; 10(1):1-14. doi:10.1186/ s12917-014-0198-3

Biernacka A, Dobaczewski M, Frangogiannis NG. TGF- $\beta$ signaling in fibrosis. Growth Factors, 2011; 29(5):196-202. doi:10.3109/ 08977194.2011.595714

Contreras-Zentella ML, Hernández-Muñoz R. Is liver enzyme release really associated with cell necrosis induced by oxidant stress? Oxid Med Cell Longev, 2016; 2016:1-12. doi:10.1155/2016/3529149

Dewi S, Isbagio H, Purwaningsih EH, Kertia N, Setiabudy R, Setiati S. A Double-blind, randomized controlled trial of ciplukan (Physalis angulata Linn) extract on skin fibrosis, inflammatory, immunology, and fibrosis biomarkers in scleroderma patients. Acta Med Indones, 2019; 51(4):303-10

Dong S, Chen QL, Song YN, Sun Y, Wei B, Li XY, Hu YY, Liu P, Siu SB. Mechanisms of CCl4-induced liver fibrosis with combined transcriptomic and proteomic analysis. J Toxicol Sci, 2016; 41(4):561-72. doi: $10.2131 /$ jts. 41.561
Ebeid HM, Gibriel AAY, AL-Sayed HMA, Elbehairy SA, Motawe EH. Hepatoprotective and antioxidant effects of wheat, carrot, and mango as nutraceutical agents against $\mathrm{CCl}$-induced hepatocellular toxicity. J Am Coll Nutr, 2015; 34(3):228-31. doi:10.1080/07315724.2 014.887486

Fabregat I, Moreno-Càceres J, Sánchez A, Dooley S, Dewidar B, Giannelli G, Dijke PT. TGF- $\beta$ signalling and liver disease. FEBS J, 2016; 283:2219-32. doi:10.1111/febs.13665

Goodman ZD. Grading and staging systems for inflammation and fibrosis in chronic liver diseases. J Hepatol, 2007; 47(4):598-607. doi:10.1016/j.jhep.2007.07.006

Li W, Yan XT, Sun YN, Ngan TT, Shim SH, Kim YH. Antiinflammatory and PPAR transactivational effects of oleanane-type triterpenoid saponins from the roots of Pulsatilla koreana. Biomol Ther, 2014; 22(4):334-40. doi:10.4062/biomolther.2014.047

Lin WC, Kuo SC, Lin WL, Fang HL, Wang BC. Filtrate of fermented mycelia from antrodia camphorata reduces liver fibrosis induced by carbon tetrachloride in rats. World $\mathrm{J}$ Gastroenterol, 2006; 12(15): 2369-74. doi:10.3748/wjg.v12.i15.2369

Luedde T, Schwabe RF. NF-кB in the liver-linking injury, fibrosis and hepatocellular carcinoma. Nat Rev Gastroenterol Hepatol, 2011; 8(2):108-18. doi:10.1038/nrgastro.2010.213

Luthfiyanti R, Iwansyah AC, Rahayu Y, Achyadi NS. Study of antioxidant activities, acceptability, and shelf life prediction of ciplukan (Physalis angulata L.) juice drinks. IOP Conf Ser Mater Sci Eng, 2021; 1011(1):1-11. doi:10.1088/1757-899X/1011/1/012001

Rengifo-Salgado E, Vargas-Arana G. Physalis angulata L. (Bolsa mullaca): a review of its traditional uses, chemistry and pharmacology. Bol Latinoam y Del Caribe Plantas Med y Aromat, 2013; 12(5):431-45.

Sebastiani G. Non-invasive assessment of liver fibrosis in chronic liver diseases: Implementation in clinical practice and decisional algorithms. World J Gastroenterol, 2009; 15(18):2190-203. doi:10.3748/ wjg. 15.2190

Shipley LC, Axley PD, Singal AK. Liver fibrosis: a clinical update. EMJ Hepatol, 2019; 7(1):105-17.

Sun L, Liu J, Liu P, Yu Y, Ma L, Hu L. Immunosuppression effect of withangulatin A from Physalis angulata via heme oxygenase 1-dependent pathways. Process Biochem, 2011; 46(2):482-8. doi:10.1016/j. procbio.2010.09.022

Weiskirchen R, Weiskirchen S, Tacke F. Recent advances in understanding liver fibrosis: bridging basic science and individualized treatment concepts [version 1; referees: 2 approved]. F1000Research, 2018; 7:1-17. doi:10.12688/f1000research.14841.1

Xiang D, Zou J, Zhu X, Chen X, Luo J, Kong L, Zang H. Physalin $\mathrm{D}$ attenuates hepatic stellate cell activation and liver fibrosis by blocking TGF- $\beta /$ Smad and YAP signaling. Phytomedicine, 2020; 78:153294. doi:10.1016/j.phymed.2020.153294

Zamin I, De Mattos AA, De Mattos ÂZ, Coral G, Santos D, Rhoden C. The vitamin E reduces liver lipoperoxidation and fibrosis in a model of nonalcoholic steatohepatitis. Arq Gastroenterol, 2010; 47(1):8692. doi:10.1590/S0004-28032010000100015

How to cite this article:

Rohmawaty E, Rosdianto AM, Usman HA, Saragih WAM, Zuhrotun A, Hendriani R, Wardhana YW, Ekawardhani S, Wiraswati HL, Agustanti N, Bestari MB, Dewi S. Antifibrotic effect of the ethyl acetate fraction of ciplukan (Physalis angulata LINN.) in rat liver fibrosis induced by CCI4. J Appl Pharm Sci, 2021; 11(12):175-182. 